\title{
O POSITIVISMO E A REPÚBLICA
}

\author{
Acacio Vaz de Lima Filho \\ Bacharel, Mestre e Doutor em Direito Civil pela \\ Faculdade de Direito da Universidade de São \\ Paulo.
}

Resumo:

No presente artigo, abordamos a influência do Positivismo na implantação do sistema republicano no Brasil, em novembro de 1889. Tratamos do ambiente politico e cultural dos derradeiros tempos do Império. aludindo ao surto das idéias novas, consubstanciadas no Positivismo de Augusto Comte, e no Evolucionismo de Herbert Spencer. Abordamos a obra dos primeiros positivistas brasileiros, referindo-nos apenas aos "não-ortodoxos", vale dizer, àqueles que, sem embargo de seguir em linhas gerais as idéias de Comte, não integravam o "Apostolado Positivista do Brasil". E demonstramos que, se o Positivismo, enquanto doutrina, forneceu o "substractum" doutrinário para a implantação entre nós do sistema republicano, não tiveram, entretanto, os "positivistas ortodoxos" qualquer participação ativa na derrubada do Império. Ela foi o fruto da pregação de Benjamin Constant Botelho de Magalhães, um "não-ortodoxo", na Escola Militar. Esta pregação produziu o braço armado que derrubou a Casa de Bragança. Implantada a República, os "positivistas ortodoxos" aderiram a ela.

Abstract:

In this article. we talk about the influence of Positivism for the implantation, in Brazil, of republicanic system. in november, 1889. We took care of political and cultural atmosphere of Empire's last years, speaking about the outbreak of new ideas, these introduced by Comte's Positivism and Spencer's Evolutionism. We have studied the works of firsts brazilian positivists, in especial, of the called "not orthodoxes" who, in spite of following in general Augusto Comte's ideas, were not members of "Apostolado Positivista do Brasil" We have demonstrated that, if Positivism. the doctrine, gave the doctrinal "substractum" for the implantation, among us, of the republican system, "orthodoxes positivists" however, did not have any participation in Brazilian Empire's fall. Brazilian Empire's fall was the consequence of Benjamin Constant Botelho de Magalhães"s preaching, a "not orthodoxe" at Military School. This preaching has produced the military conditions to destrone Casa de Bragança. After the implantation of Republic, the "orthodoxes positivists" followed it.

Unitermos: Ambiência cultural do século XIX; Positivismo: Evolucionismo.

Keywords: Positivism; Evolutionism; Century XIX's: Culture Scene. 
Sumário: 1) Introdução: A origem deste artigo; 2) Breves considerações sobre o Segundo Reinado; 3) Os primeiros positivistas brasileiros; 4) A influência do Positivismo na implantação da República; 5) Conclusão; 6) Bibliografia.

\section{Introdução: a origem deste artigo}

No ano de 1975, nos Cursos de Pós -Graduação desta Casa, apresentamos ao ilustre Professor Miguel Reale, na Cadeira de "História das Idéias Jurídicas no Brasil no Século XIX", um trabalho semestral com o título de "Os Adeptos de Augusto Comte e a República", no qual procuramos estudar a influência da doutrina positivista no movimento politico e militar que desembocou nos acontecimentos de 15 de Novembro de 1889. Para a elaboração do referido trabalho valemo-nos, então, não apenas da bibliografia que nos fora recomendada pela cátedra, mas também dos subsídios que colhemos nos seminários da matéria, presididos pelo Professor Aloysio Ferraz. Pereira, hoje aposentado.

Quase trinta anos são passados desde então. Veio o fim do regime militar, com a devolução do poder ao estamento civil. Veio a Constituição de 1988. O Brasil passou, inclusive, no ano de 1993, por um plebiscito envolvendo a volta da Monarquia, ou a continuação da República. E começamos a pensar se não seria oportuna uma releitura crítica do trabalho apresentado ao Professor Miguel Reale, com a sua eventual publicação. Dois motivos foram determinantes para a nossa decisão de rever e publicar aquele pequeno trabalho. Em primeiro lugar, existe a nossa firme conviç̧ão de que, mais de um século depois da imposição manu militari da República, o Exército Brasileiro. que desempenhou um papel de destaque nos acontecimentos de 15 de Novembro de 1889, e que acabara de exercer uma influência fortíssima na recente História do Brasil (da Revolução de Março de 1964 ao fím do Governo do General Figueiredo), continuava a ser, no seu "inconsciente colctivo" positivista. E, em segundo lugar. o plebiscito sobre a Monarquia nos deu uma perspectiva nova do espaço/tempo em que se ubicam estas duas realidades políticoinstitucionais, a Monarquia e a República. Por outras palavras, os eventos do dia 15 de Novembro de 1889 estão muito próximos de nós outros, os brasileiros do dealbar do século XXI. Pareceu-nos, de conseguinte, que seria interessante repensar a proclamação da República. do ponto de vista do substractum das idéias a ela conducentes. $\mathrm{E}$ isto porquanto pensamos agora, como pensávamos então, que o 
sistema republicano, estranho às nossas tradições políticas, e uma imitação de modelos estrangeiros, é a fonte de muitas de nossas mazelas. Não deixa de ser tragicamente irônico que o Exército que, implantando a República, extinguiu entre nós o "Poder Moderador" exercitado pelo monarca, passasse a ser um "poder moderador atípico" cujas intervenções na vida pública são cruentas, ao contrário do que sucedia com o tradicional "Poder Moderador" do Império!...

A República foi e é entre nós, em termos institucionais, um corpus extraneus. E este dado foi magistralmente registrado por Eduardo Prado, o qual assim aborda as relações entre o Brasil e os Estados Unidos da América:

"Pensamos que é tempo de reagir contra a insanidade da absoluta confraternização que se pretende impor entre o Brasil e a grande república anglo-saxônia, de que nos achamos separados, não só pela grande distância, como pela raça, pela religião, pela indole, pela lingua, pela história e pelas tradições do nosso povo.

O fato de o Brasil e de os Estados Unidos se acharem no mesmo continente é um acidente geográfico ao qual seria pueril atribuir uma exagerada imporiancia" !

Razão assistia ao autor patrício. Numerosas colônias ibero-americanas que adotaram o sistema republicano de governo copiaram servilmente o modelo norte-americano, inclusive no que tange ao nome adotado para os diversos Estados: -- "Estados Unidos Mexicanos" "Estados Unidos do Brazil" e assim por diante... e os resultados, nefastos, deste arbitrário transplante de instituições alienígenas, não se fizeram esperar. O caudilhismo, contrafação macabra do presidencialismo, rapidamente se espalhou pelo continente americano, deitando raízes, inclusive, no Brasil. Os "pronuniciamicntos" e quartcladas grassaram em solo latino-americano. E o "homem providencial" o "salvador da pátria", veio a substituir, no imaginário popular, a figura paternal do Rei ou do Imperador. Tudo isto recomenda, cremos, que a chamada "Proclamação da República" seja reavaliada, com equilibrio c serenidade.

1. Vide "A Ilusão Americana". 2. ed. São Paulo: Editora Brasiliense, 195x. p. 7. 
Mantivemos a estrutura básica do nosso trabalho escolar, acrescentando-lhe alguns itens. Enriquecemos a bibliografia utilizada. E alteramos o título para o ora adotado, que nos pareceu mais consentâneo com a publicação em uma revista do meio acadêmico.

2. Breves considerações sobre o Segundo Reinado

As grandes transformações políticas, as drásticas rupturas institucionais, não surgem do nada. Têm elas, ao revés, antecedentes que muito dificilmente podem ser reduzidos a uma causa única. Há sim, com freqüência, as "concausas" E a instauração do sistema republicano entre nós, não foge a esta regra. Também a República teve antecedentes, inclusive --- e quiçá predominantemente --- doutrinários. Assim, o estudioso da História das Idéias que quiser fazer uma pesquisa séria sobre a implantação do sistema republicano no Brasil, terá que se debruçar sobre a ambiência cultural dos últimos tempos do Império.

Machado Neto, em seu "História das Idéias Juridicas no Brasil" usa como epigrafe do capítulo II uma candente passagem de Silvio Romero, que aqui merece transcrição:

“Até 1868 o catolicismo reinante não tinha sofrido nestas plagas o mais leve abalo; a filosofia espiritualista, católica e eclética, a mais insignificante oposição; a autoridade das instituições monárquicas, o menor ataque sério por qualquer classe do povo, a instituição servil e os direitos tradicionais do feudalismo prático dos grandes proprietários a mais indireta opugnação; o romantismo, com seus doces, enganosos e encantadores cismares, a mais apagada desavença reatora. Tudo tinha adormecido à sombra do manto do principe feliz que havia acabado com o caudilhismo nas províncias e na América do Sul e preparado a engrenagem da peça política de centralização mais coesa que já uma vez houve na história em um grande país. De repente, por um movimento subterrâneo, que vinha de longc, a 
instabilidade de tôdas as coisas se mostrou e o sofisma do império apareceu em tôda sua nudez. A guerra do Paraguai estava ainda a mostrar a tôdas as vistas os imensos defeitos de nossa organização militar $e$ o acanhado de nossos progressos sociais, desvendando repugnantemente a chaga da escravidão; e então a questão dos cativos se agita e logo após é seguida da questão religiosa; tudo se põe em discussão: o aparelho sofístico das eleições, o sistema de arrôcho das instituições policiais e da magistratura e inúmeros problemas econômicos; o partido liberal expelido grosseiramente do poder, comove-se desusadamente $e$ lança aos quatro ventos um programa de extrema democracia, quase verdadeiramente um socialismo; o partido republicano se organiza e inicia uma propaganda tenaz que nada faria parar. Na política é um mundo inteiro que vacila. Nas regiões do pensamento teórico o travamento da peleja foi ainda mais formidável, porque o atraso era horroroso. Um bando de idéias novas esvoaça sobre nós de todos os pontos do horizonte" 2

Adverte Machado Neto que, a despeito dos exageros, o texto reproduz, no essencial, a transformação pela qual passava o Brasil, no início do último quartel do século XIX. Realmente, havia no país "um bando de idéias novas" Idéias novas que foram representadas pelo Positivismo e pelo Evolucionismo. O primeiro, puro ou heterodoxo, difundiu-se principalmente no Sul do país (Rio de Janeiro, São Paulo e Rio Grande do Sul); o segundo, teve sua principal sede na Escola do Recife. ${ }^{3}$

Mas, como veremos ao longo deste artigo. os positivistas sofriam influências evolucionistas. Os dois principais polos de criação cultural, quanto à teoria jurídica (que é o nosso tema), eram as Faculdades de Direito de São Paulo e do

2. Vide "História das Idéias Jurídicas no Brasil". São Paulo: Fditorial Grijalbo Lıda - Editora da Universidade de São Paulo, 1969. p. 45 - itálico no original.

3. Vide "História das Idéias Jurídicas..." cit., p. 46. 
Recife. Na primeira, nossa Casa. repita-se, dominou o Positivismo. Na segunda, o Munismo Evolucionista. O Positivismo, tanto na Europa, como em nosso meio cultural, precedeu o Monismo.

Cremos não ser possível isolar o Evolucionismo de inspiração spenceriana, do pensamento do proprio Augusto Comte. Ambos, o Positivismo e o Evolucionismo, integram o pensamento do século XIX, padecendo os dois dos males do reducionismo e do cientificismo que, de maneira indelével, marcaram o pensamento daquela centúria. Aliás, é o próprio Spencer quem, em seu "Classifícação das Sciencias", faz o panegírico de Comte, escrevendo, verbis:

"O que Comto tinhu em vistu era dar ao pensamento e ao methodo philosophico uma fórma e uma organisaşão mais perfeita, e applical-os á interpretação das classes de phenomenos que não tinham ainda sido estududas de modo philosophico. Era concepção grandiosa, e tental-a realisar era empresa digna de sympatia e de admiração" +

Mais adiante, entretanto, o pensador inglês coloca em dúvida o fato de Augusto Comte haver sido bem sucedido, em sua tentativa de sistematização de todas as ciências:

"Em vez de uma concepção obscura e vaga, Comte apresentou ao mundo uma concep̧̧ão clara $\epsilon$ distinctamente definida. Realisando esta concepcão, mostrou notavel grandeza de idéas, grande originalidade, immenso genio de invenção. e extraordinario poder de generalisação. Considerado em si mesmo, o seu systema de philosophia positiva, verdadeiro ou falso, é monumento de proporções gigantescas. Mas, depois de ter concedido a Comıe a grande admiração que elle merece

4. Vide "Classificação das Sciencias", tradução de M.C. da Rocha. 2. ed. Rio de Janeiro: Laımment \& C., 1900. p. 62. 
pela sua concepção, pelos seus esforços para realisal-a, $e$ pelo talento que desenvolveu nesta tentativa, resta uma pergunta a fazer-se: Foi elle bem sucedido? Um pensador que reorganisa o methodo scientifico e os conhecimentos do seu seculo, e que faz accitar a seus succesores a reorganisação que tentou, póde ser, com justa razão, considerado chefe de escola, e aquelles podem ser considerados seus discipulos. Mas, entre os successores, os que aceitam o methodo e os conhecimentos do seculo, porém não aceitam a reorganisação, não são certamente seus discipulos. Ora, o que aconteceu cm relação a Comte? Ha alguns, mas em pequeno numero, que adoptaram as suas doutrinas quasi sem reserva; e estes podem ser verdadeiramente chamados seus discipulos. Ha outros que aceitam como verdadeiros certo numero destes principios, mas que rejeitam o resto; estes, se são seus discipulos, são apenas em parte. Finalmente, ha outros que rejeitam a sua doutrina em tudo o que ella tem de particular; e estes devem ser considerados seus antagonistus" 5

Temos para nós que, embora Herbert Spencer se proclame uma "antagonista" de Augusto Comte, ${ }^{0}$ o Evolucionismo pode ser considerado, não um desenvolvimento do Positivismo, mas um movimento de idéias que se enquadra, tal qual o Positivismo, nos cânones do pensamento do século XIX. De conseguinte, no Brasil, os partidários de um e de outro dos dois sistemas filosóficos estavam mais próximos uns dos outros, do que poderiam supô-lo em sua época.

Ainda antes dos anos 70 do século XIX, época enfocada por Silvio Romero no texto transcrito "retro", em termos de pensamento filosófico, já tinham ocorrido manifestações isoladas de inconformismo contra a doutrina eclética;

5. Vide "Classificação das..." cit., p. 63-64

6. Op. cloc. cit. 
inconformismo decorrente da obra de Comte, das doutrinas de Darwin e do conhecimento da obra, produzida na Alemanha, dos chamados "hegelianos de esquerda" Esta a lição de Antonio Paim. Ao abordar o que chama de o "Significado do surto de idéias novas" leciona o mestre patrício:

"Embora discordando da maneira pela qual Silvio Romero apresentava o problema, exagerando o papel desempenhado neste movimento pela Escola do Recife, José Veríssimo atribui-lhe idêntica significação $e$ caracteriza-o de maneira bem mais profunda, tanto no que se refere às circunstâncias que o propiciaram como à amplitude que veio a assumir"?

E prossegue o pensador brasileiro, verbis:

"Em relação ao pensamento filosófico, deve-se considerar como estabelecida, em definitivo, a existência, muito anterior aos anos 70, de manifestações isoladas de inconformismo com a doutrina eclética e do conhecimento das obras de Comte, da repercussão das doutrinas de Darwin, da crítica religiosa iniciada, na Alemanha, pelos chamados hegelianos de esquerda e continuada por Renan e outros etc. Contudo, o toque de alarme havia que partir da arena política desde que o sistema de idéias que se passou a combater, segundo o indicou, acertadamente, Silvio Romero, como qu' se enfeixava em mãos da monarquia e nos muitos instrumentos que lhe serviam de suporte" $^{8}$

7. Vide "História das Idéias Filosóficas no Brasil". 2. ed. São Paulo: Editora da Universidade de São Paulo - Editorial Grijalbo Ltda., 1974. p. 255.

8. Op. e loc. cit. - grifos nossos 
Se as idéias a combater estavam personificadas na Monarquia, e nos instrumentos à sua disposição, e se "o alarme devia partir do campo da política" não ¿́ de causar estranheza que, de maneira maniqueísta, os adeptos do sistema republicano ligassem, à instituição monárquica, tudo o que, de retrógrado e de indesejável, havia no Brasil da época. F aqui, é de se notar que, nos comç̧os da década de 60 do século XIX, o Império atingira a sua plenitude. Plenitude que uma guerra externa, a do Paraguai, de certa forma prolongou.

Como é sabido, no Segundo Reinado as duas forças políticas mais atuantes eram o Partido Liberal e o Partido Conservador. I:m 1869, uma vez fora do poder, os liberais lançaram um programa, que era o mais avançado da época. E o ano de 1870, assinalou a fundação do Partido Republicano. Este veio a realizar a célebre "C'onvenção Republicana de Itu" instalada aos 18 de Abril de 1873. como o refere Plínio Salgado. "na residência senhorial onde hoje está instalado o Museu Republicano" ${ }^{9}$ Assim, todas as reivindicações liberais, assumiram feição nitidamente antimonárquica. Era como se, para os males da nacionalidade. a República fosse uma panacéia infalível. Surgiu, nos círculos intelectuais de um modo geral, e na mocidade acadêmica em particular, um "espirito crítico" Devemos advertir que inexistiam correntes delineadas de pensamento. o que externava o inconformismo, por este simples motivo, já era uma idéia simpática. E a mocidade se atirava, desordenadamente, à leitura dos mais variados autores, como Augusto Comte, Littré. Taine, Renan, Darwin, e Antero de Quental. ${ }^{10}$

Com a fundação da Sociedade Positivista. no Rio de Janeiro, Miguel Lemos. Teixeira Mendes e Pereira Barreto começaram a lançar suas primeiras obras. E a filosofia eclética. até então não contestada. passou a sofrer ataques frontais.

O mundo oficial, não ficou alheio à renovação. Tiveram lugar:
a. A reforma do Colégio de D. Pedro Il;
b. A organização da Escola Politécnica;
c. A fundação da Escola de Minas. em Ouro Preto;
d. A contratação de professores estrangeiros;
e. A reforma do Museu e da Biblioteca Nacional.

9. Vide "História do Brasil". São Paulo: Editora F.T.D. S.A., 1970. v. II, p. 158.

10. Op. cit., p. $46-47$ 
3. Breves considerações sobre os primciros positivistas brasileiros

Cremos que tem interesse acadêmico, dizer alguma coisa sobre os primeiros positivistas brasileiros. Abster-nos-emos, na medida do possível, de tratar de seus dados biográficos, cingindo-nos aos aspectos doutrinários, do seu relacionamento com as teses de Comte. Aqui não vamos abordar os membros do "Apostolado Positivista" Enfocaremos pois os nomes de Luís Pereira Barreto, Paulo Egydio, Alberto Salles, João Monteiro, Pedro Lessa e Josć Mendes. Ao abordá-los, Machado Neto afirma que Paulo Egydio era o mais sociólogo, Alberto Salles o mais filósofo, e João Monteiro, o mais jurista. ${ }^{11}$

Entre os primeiros positivistas que, entre nós, divulgaram as doutrinas comtcanas, merece um especial destaque a figura de Luís Pereira Barreto. Nascido em 1840, e médico diplomado na Bélgica, foi ele o autor da primeira obra positivista publicada neste país. Era um positivista convicto, embora, de acordo com Machado Neto, fosse um "não ortodoxo" Num parêntesis, diríamos que o mestre da Universidade da Bahia é extremamente feliz ao usar, aqui, a palavra "ortodoxo" O étimo costuma ser ligado às religiões, e a sua aplicação ao Positivismo é, inclusive, uma fina ironia. Em São Paulo, o Dr. Pereira Barreto presidiu a constituinte estadual republicana. Espírito polimorfo. foi médico, jornalista, e entusiasta das campanhas em favor da imigração européia, da abolição da escravatura, da República, da viticultura, da melhoria genética do rebanho bovino e outras. Sua obra fundamental é "As Três Filosofias" em três volumes, o primeiro dedicado à Filosofia Teológica, o segundo à Filosofia Metafísica, e ainda um terceiro, o conclusivo, sobre a Filosofia Positiva, que não chegou a ser escrito, em função de, em Portugal, Teófilo Braga haver publicado um livro sob o mesmo título, e voltado para o mesmo assunto. Divergem as opiniões, sobre os méritos desta obra de Pereira Barreto. Miguel Lemos taxou-a de "manta de retalhos escandalosamente plagiados", ao passo que João Cruz Costa afirma que tal opinião é injusta para com o iniciador do Positivismo no Brasil, atribuindo tal conduta a quantos "se fanatizam por uma teoria ou por uma idéia" 12

11. Vide "História das Idéias Jurídicas..." cit., p. 47

12. Vide "Contribuição à História das Idéias no Brasil". p. 159, apud. Machado Neto, op. cloc. cit. 
Refere Machado Neto que o Professor Roque Spencer Maciel de Barros demonstrou o acerto da critica de Miguel Lemos a Pereira Barreto. ${ }^{13}$ Para nós, em um artigo publicado na Revista desta Faculdade de Direito, importa o dado de que o médico-filósofo de Jacareí, fiel ao seu mestre Augusto Comte, era profundamente hostil aos cultores do Direito. Damos a palavra a Machado Neto:

"Se Augusto C'omte já apodara os juristas de classe eminement méthaphysique des jurisconsultes" 4 , seu discipulo brasileiro não fazia por menos. Sua ojeriza aos homens de direito tornou-se notória acoimando-os também de metafisicos e acusando-os de "fazer leis, quando a ciència não as faz, mas sim as descobre"5 Costumava opor o médico e o engenheiro como expressões do ideal cientifico-tecnicista do periodo positivo ao bacharelismo literário e metafisico dos legistas". $6^{14}$

Aqui é de interesse mencionar que Pereira Barreto foi um implacável adversário da Faculdade de Direito de São Paulo. Para ele, a Academia disseminava no país, anualmente. "uma onda calculada de saber falso, de virtudes falsas e de anarquia certa" 15

Refere Machado Neto que se Pereira Barreto era um adversário figadal do Direito e dos juristas, Paulo Egydio de Oliveira Carvalho, nascido em 1842 e falecido em 1905, era ao revés um profissional do Direito de formação spenceriana, e dotado da "vocação da síntese dos cientifícismos de Spencer. Comte e Darwin"10 Estava. porém. como Luís Pereira Barreto, "encharcado" do cientificismo positivista

13. Op. cit., p. $47-48$

14. Op e loc. cit.

15. Vide "As Três Filosofias", "in" "Obras Filosóficas”. São Paulo: Grijalbo. 1957. p. 135, apud. Machado Neto, op. e loc. cit.

16. Op. cil., p. $51-52$ 
do seu tempo. ${ }^{17}$ Como Machado Neto se reporta ao "cientificismo" do século XIX, cremos oportuno registrar, neste passo, o que o saudoso Professor José Carlos de Ataliba Nogueira diz da ciência daquela centúria, na sua notável obra sobre o drama de Canudos:

"Aliás, Os Sertões foram concebidos e escritos à luz de conclusões recentes ' fugaces de uma pseudociência do século XIX. Os postulados desta "ciência" improvisada não resistiram à crítica do século XX. Geologia, biologia, botânica, geografia, meteorologia, sociologia, antropologia, etnologia, psicologia. psiquiatria, ciências médicas, história, criminologia, justiça social e outros ramos do saber viram a renovação completa dos seus postulados, neste século, com o desmentido de quanto afirmavam. O avanço cientifico, no nosso século, foi surpreendente e desmedido". $77^{18}$

Em outro livro da sua lavra, o ilustre Catedrático de Teoria Geral do Estado desta Faculdade afirmou ... segundo cremos, com acerto --- que o século XIX foi ... "contraditório, romântico e estúpido". $18^{19}$

Cremos ser oportuno que bem nos fixemos sobre o espírito do século XIX $\mathrm{cm}$ geral, e em particular, sobre o espírito da ciência daquele século. A plena apreensão de tal espírito é básica para a compreensão do papel descmpenhado pelos seguidores de Augusto Comte, na implantação da República em 1889. Os homens de ciência depositavam uma fé inabalável, e até ingênua, nos postulados que consideravam "científicos" Aliás, era uma fé bem pouco própria de quem descjava se libertar da Metafísica... o nome de um conhecido e respeitado colégio do Interior de São Paulo é revelador desta mentalidade. Referimo-nos ao "Ginásio Culto À

17. Op. cit., p. 52

18. Vide "António Conselheiro e Canudos". São Paulo: Companhia Editora Nacional, 1974. p. 3031 grifos no original

19. Vide "Pena sem Prisão". 2. ed. São Paulo: Edição Saraiva. 1956. p. 123. 
Ciência", de Campinas. É possível que tenha sido batizado no século XX. Seja como for, u nome é um espelho, fiel. da mundividência dos homens do ocaso do Império.

Voltemos a Paulo Egydio. Fiel a Comte, ele buscou na Sociologia a fundamentação cientifica para a Jurisprudência. Aqui, empregamos a palavra em seu sentido de "Ciência do Direito", utilizado por Miguel Reale. ${ }^{20}$ Ao comentar o apego do evolucionista brasileiro à Sociologia, escreve Machado Neto:

"Mas, tal é a confiança ingênua que deposita na novel ciência da sociedade que acaba por submergir a velha jurisprudência nas águas envolventes da sociologia" 21

Aliás, Paulo Egydio chegou a escrever que o Direito era uma parte da Sociologia... o que, pensamos, era um corolário da sua formação e da sua época. Ao transportar o Evolucionismo para o plano do Direito, afirmou Paulo Egydio, "verbis":

"Circunscrevendo as nossas observações ao ramo da sciencia social, do qual nos ocupamos --- a sciencia juridica --- podemos affirmar, em face dos melhores documentos da cultura juridica contemporanea, este facto decisivo: que os mais solidos productos culturaes daquella disciplina hão sido elaborados à sombra e sobo influxo da doctrina evolucionista" 22

De acordo com Machado Neto, no intelecto de Paulo Egydio as orientações que prevaleciam eram o positivismo comteano e o evolucionismo spenceriano, ${ }^{23}$ o que, acreditamos, justifica o que dissemos "retro" a propósito da existência de algum parentesco intelectual, de alguma afinidade, entre as doutrinas de

20. Vide "Lições Preliminares de Direito" 16. ed. São Paulo: Editora Saraiva, 1988. p. 62

21. Vide "História das Idèias Jurídicas..." cit., p. 52

22. Vide "Ensaios sobre algumas questō's de Direito e de Economia Politica". p. 84, apud. Muchado Neto, op. cit., p. 53

23. Op. e loc. cit. 
Augusto Comte e as de Herbert Spencer. E a fé inabalável na ciência, à qual aludimos há pouco, está presente na otimista conclusão de um ensaio - "Estudos de Sociologia Criminal - Do Conceito Geral do Crime Segundo o Methodo Contemporâneo" em que Paulo Egydio prevê um constante decréscimo da criminalidade, ligado ao progresso da Humanidade.

Um outro nome que devemos mencionar é o de Alberto Salles (1857 1904). Foi um positivista que, segundo Machado Neto, no essencial. não fugia ao sociologismo. ${ }^{24}$ Considerava Augusto Comte "o mais original e o mais robusto pensador do século" não sendo, entretanto, um positivista ortodoxo. $\mathrm{Na}$ opinião de Luiz Washington Vita, citado pelo autor da Bahia, Alberto Salles fundia Positivismo, Evolucionismo e Materialismo. ${ }^{25}$ A irreligiosidade está presente na obra deste positivista. sendo ela aliás - como bem pondera Machado Neto - uma característica dos intelectuais daquele tempo. Um dado a respeito de Alberto Salles que muito nos importa. é o de que ele se destacou como um publicista que defendia o sistema republicano, a tal ponto que recebeu do citado Luiz Washington Vita o epíteto de "ideólogo da República" ${ }^{26}$ Deixou ele obras como "Sciencia Politica" "Politica Republicana" e o opúsculo "Catecismo Republicano" além do "Ensaio sôbre a moderna concepção do Direito" Nesta derradeira obra é que, para o Professor Machado Neto, se encontra a sua "contribuição mais pessoal em matéria de teoria jurídica". ${ }^{27}$

O entusiasmo cientificista de Alberto Salles pelo Direito o levou a afirmar que, após entrar em sua "fase positiva" ele haverá de eliminar de si o elemento coercitivo. ${ }^{28}$ Não deixa de ser pitoresco, pensamos nós, que um materialista tenha escrito uma obra chamada "Catecismo Republicano!.." (grifo nosso).

Passemos a João Monteiro. Positivista embora, afastou-se de Comte, ao defender o Direito e a sua ciência. Foi ele, de acordo com Machado Neto, "o mais jurista" dos autores positivistas de São Paulo. ${ }^{29}$ Com efeito, dedicando-se ao processo,

24. Op. cit., p. 57

25. Op. eloc. cit.

26. Op. cit., p. 58

27. Op. e loc. cit.

28. Op. cil., p. 60

29. Op. eloc. cit. 
era conhecedor dos estudos alemães e italianos da matéria, com os quais "soube fecundar o praxismo de origem lusa" ${ }^{30}$ Ainda para o mesmo autor, as convicções filosóficas de João Monteiro eram, em termos fundamentais, calcadas no evolucionismo de Spencer, sem embargo de participar ele do "espírito positivo" e do cientificismo que, como já assinalamos "retro", foram a marca de toda uma época. Vejamos o que o Professor Miguel Reale registra sobre o mestre desta Faculdade:

"Jurista elevado ao plano das idéias gerais, procurando estabelecer harmonia entre as suas conviç̧ões filosóficas e o tecnicismo de sua disciplina, seguiu ele caminho diverso em seu roteiro mental, dando mais justo valor às contribuições da Escola Histórica ou de Jhering, na edificação objeliva do Direito, sem olvidar o que de especifico e próprio existe na Jurisprudencia" 31

Ainda para o Professor Reale, a nova geração de professores do início da Era Republicana, estava impregnada do "cientificismo" 32 Mais adiante, aduz o antigo Catedrático de Filosofia do Direito das Arcadas:

"Conhecedor cuidadoso do Direito Pátrio, João Monteiro não se contentava com os horizontes da positividade juridica nacional, pregando, como realidade em futuro mais ou menos próximo, a cosmopolização do Direito 49" 33

Um dado posto em realce pelo Professor Miguel Reale. tem, cremos, um grande relevo: - $\mathrm{O}$ ideal da universalização - do Direito, das línguas, das

30. Op. cit., p. 60-61.

31. Vide "Filosofia Em São Paulo" 2. ed. rev. reest. São Paulo: Grijalbo -- Edrtora da Universidade de São Paulo, 1976. p. 147

32. Op. e loc. cit.

33. Op. cit., p. 148 - itálico no original 
civilizações - em João Monteiro, não estava baseado, à maneira dos jusnaturalistas, na "unidade essencial do homem". porém com apelo às "verdades científicas" 34

Tratemos agora de Pedro Lessa. cujo nome apresenta um extraordinário interesse para nós, uma vez que foi, ele, o primeiro professor de Filosofia do Direito desta Casa, após a tradicional cadeira de Direito Natural ser rebatizada. Foi ainda, o mineiro Pedro Lessa (1859 1921), Ministro do Supremo Tribunal Federal. ${ }^{35}$ Em nossa opinião. dentre os positivistas brasileiros, foi ele o dotado de intelecto mais lúcido, e de um espírito verdadeiramente universal, que o conduziu à heterodoxia, e de conseguinte, à rejeição da "lei dos três estados" de Augusto Comte. Mais ainda, o antigo professor da Academia de São Paulo aceitou o que Machado Neto denomina "a inevitabilidade da metafísica" e a convivência da ruligião com a ciência e a filosofia, sendo que, em matéria de Política, orientou-se para um ideal socialista. Pedro Lessa, ainda de acordo com o magistério do pensador da Bahia, também se distanciou de Comte, no que tange à condenação do Direito. ${ }^{36}$

Há uma informação interessante sobre Pedro Lessa, que aponta para o fato de ele ter sido, presumivelmente, um ótimo didata. ('om efeito, em sua clássica biografia de Monteiro Lobato, Edgard Cavalheiro reproduz uma confīssão do escritor taubateano pertinente à sua vida estudantil, e ao juízo que fazia dos professores das Arcadas:

"A minha idéia sôbre todos aquêles professôres devia ser que não passavam duns "perobas" Mas houve duas exceções. Adorei Pedro Lessa e nunca perdi uma paluvra de Almeida Vogueira. Eram artisticamente inteligentes"37

Um ponto de divergência untre a concepção jurídica de Pedro Lessa e a ortodoxia positivista, bem como com o cientificismo naturalista da sua época,

34. Op. E' loc. cit.

35. V., de Machado Neto. op. cit., p. 63

36. Op. e loc, cit.

37 Vide "Monteiro Lobato - Vida e Obra" São Paulo: Companhia Distribuidora de Livros Companhia Editora Nacional, 1955. v. I, p. 62-63-grifos nossos 
apontado por Machado Neto, se ubica na concepção lessiana do Direito Natural. Embora criticada por Miguel Reale, remanesce o dado de que o seu predecessor na cátedra reconhecia a existência de "principios fundamentaes, necessarios, sempre os mesmos" sobre os quais repousariam todas as legislações de todos os paises, em quaisquer períodos históricos. ${ }^{38}$

Pedimos vênia para registrar aqui uma informação que nos veio da nossa militância na Advocacia: - Foi Pedro Lessa, quando Ministro do Excelso Supremo Tribunal Federal, um dos pioneiros, no Brasil, da tese da reparabilidade dos danos puramente morais. antecipando-se assim, profeticamente, ao grande Orozimbo Nonato. E isto demonstra, cremos, que o jusfílósofo não descurava a concreção do Direito...

José Mendes é o derradciro autor que aqui vamos abordar. Foi, como o ensina Machado Neto, discípulo de Pedro Lessa, sendo que publicou, no ano de 1905 , "Ensaios de Philosphia do Direito" livro cujo objetivo didático, era o de servir aos alunos do seu mestre. ${ }^{39}$ José Mendes considerava ('omte e Spencer "os dois maiores pensadores do século XIX"

De Spencer aceitava, em particular, a classificação das formas do saber. e a crítica à "lei dos três estados" 40 Adotava o discípulo de Pedro Lessa o conceito de Direito do seu mestre: - "Conjunto orgânico das condições de vida e desenvolvimento do individuo e da sociedade, dependentes da vontade humana e que é necessário sejam garantidas pela fôrça coercitiva do Estado" Chama, às fontes, "orgams reveladores do direito" E estabelece uma vinculação que Machado Neto considera "curiosa" entre a teoria tradicional das fontes e a "lei dos três estados" de Augusto Comte:

"Para a escola theologica, a fonte do direito está em Deus. Para a escola racionalista. está na razão humana. Para a escola positiva, está nas necessidades sociais, que se revelam por aqueles quarro mencionados orgams" Os "orgams" seriam as decisões dos chefes, os costumes, as

38. Op. cil., p. 66

39. Op. cit. p. 67

40. Op. cit.. p. 68 
leis e o trabalho dos jurisias. ${ }^{4 l}$ A inspiração do Evolucionismo de Herbert Spencer é visivel quando José Mendes lobriga o fundamento do Direito "na necessidade de conservação e desenvolvimento do indivíduo. da sociedade e da espécie" 42

Cremos que este rápido apanhado sobre os primeiros positivistas brasileiros, serviu ao nosso escopo básico, que era o de dar aqui um esboço da vida intelectual dos últimos tempos do reinado de D. Pedro II.

4. A influência do positivismo na implantação da república

No dizer de Antonio Paim, o surto de idéias novas deve ser considerado "a ante-sala da ascenção do positivismo no Brasil" "43 Mas, ensina o mesmo autor, esse surto ressente-se de qualquer unidade doutrinária. Havia, talvez, apenas unidade de objetivos: - a crítica ao pensamento e às instituições vigentes. ${ }^{44}$

O espírito crítico citado, esteve em ascensão a partir da década de 70 do século XIX. Sofreu um processo de diferenciação, ${ }^{45}$ que o conduziu à formação da Escola do Recife e do Positivismo. Das duas correntes, para o nosso objetivo, interessa apenas a última.

Adverte Antonio Paim que "A exemplo de outras doutrinas européias, também o sistema de Augusto Comte experimentou, em terras brasileiras, um processo acentuado de diferenciação" $\mathrm{O}$ ano de 1876 assinalou a fundação da "Sociedade Positivista do Brasil" que teve uma continuadora na "Igreja Positivista do Brasil" cujo templo foi construído na década de noventa do mesmo século, no Rio de Janeiro, à Rua Benjamin Constant. O objetivo da "Igreja", aliás existente ainda hoje, era preservar a doutrina de Comte, em sua pureza original. Assim. jamais passou, a

41. Op. eloc. cit.

42. Op. eloc. cit.

43. Vide "História das Idéias Filosóficas no Brasil", cit.. p. 257

44. Op. e loc. cit.

45. Op. cit., p. 258 
mencionada "Igreja Positivista do Brasil", de "uma pequena scita" no dizer de Antonio Paim. ${ }^{46}$ Este dado importa, e muito, para o presente artigo: - As preocupações políticas, se é que existiam, jamais foram as mais importantes para a "Igreja Positivista do Brasil" Coisa interessante é esta:

Os adeptos de uma concepção que se pretendia antimetafísica, organizavam-se em uma entidade à qual davam o nome de "Igreja”!...

Ocorre que, à sombra do Positivismo, construiu-se uma facção política. Esta, como é óbvio, tem um grande interesse para nós. Antonio Paim afirma algo que muito importa ao conhecimento pleno da instauração do sistema republicano no Brasil: --- A influência politica do comtismo, é fenômeno posterior à República. ${ }^{47} \mathrm{E}$ cita José Veríssimo, para quem muitas das idéias, cuja paternidade os positivistas "a posteriori" reclamaram, faziam parte do acervo comum aos espíritos liberais da época em que surgiram. Tais, por exemplo, as idéias relativas ao casamento civil, à separação Igreja-Estado, à federação e ao regime presidencial. Com visivel ironia, diz Veríssimo:

"Quase foram eles, ao seu próprio parecer, que fizeram a emancipação dos escravos, eles que, com a má fé inconsciente c característica de todas as teologias, inclusive a positivista, escreveram que Benjamim Constant só à ultima hora tomara parte no movimento abolicionista porque "ele não havia assimilado as lições do fundador da Religião da Humanidade". Não precisou assimilá-la ou sequer conhecê-la a enorme maioria dos abolicionistas brasileiros" 48

Diversa da de Antonio Paim, é a opinião de Cruz Costa. Para este autor. foi em virtude da pregação das idéias de Comte na Escola Militar, por Benjamin Constant, que se conseguiu, para a propaganda republicana, o "apoio mais decisivo

46. Op. cit., p. 303

47. Op. eloc. cil.

48. In "O Positivismo no Brasil" "Estudos de Literatura Brasileira". Rio de Janeiro: Gamier, 1901. p. 56. apud. Antonio Paim, op. e loc. cit. - grifos nossos 
para o advento do regime republicano no Brasil: o da juventude militar" 49 Mais: $\mathrm{O}$ ingresso de Benjamin Constant na Escola Militar, deu-sc em 1852, e já nessa época, aí incontrou um ambiente muito influenciado pela filosofia de Augusto Comte. ${ }^{50}$

Ao abordar o pensamınto de Comte em suas relações com o advento da República, ensina Cruz Costa que as primeiras manifestações, entre nós, da doutrina comteana, datam de 1850. Em fevereiro desse ano, na Escola Militar, Manuel Joaquim Pereira de Sá apresentou uma tese de doutoramento sobre os princípios da estática. $^{51}$

Volvamos a Benjamin Constant Botelho de Magalhães. Já em 1867, em suas cartas à esposa, fazia referências ao Positivismo religioso. Mais tarde, esse homım veio a se desligar do "Apostolado Positivista do Brasil" Na opinião de Cruz C'osta, Benjamin Constant não era um positivista ortodoxo, e a República não foi obra dos positivistas do Apostolado. Quanto aos positivistas ortodoxos, e trata-se de Miguel Lumos e Teixeira Mendes, é interessante notar que, antes de aderirem ao Posilivismo, diziam-se republicanos. ${ }^{52}$ Uma vez positivistas, estes, os ortodoxos, dóceis aos preceitos do "Manifesto Inicial da Sociedade Positivista de Paris" (de (omte), seriam republicanos, porquanto é preciso que tenhamos em conta que Augusto Comte era um republicano convicto, sobre ele escrevendo Oliveira Viana, verbis:

"Augusto Comte, apesar de suas origens tradicionalistas, apesar de seu temperamento "direitista" apesar de suas lcituras de De Maistre, De Bonald e outros autores desta escola, tornara-se republicano, muito moço ainda. mercê das influências do meio escolar. Em seus verdes anos escreveu um ensaio violentissimo contra a Restauração. Luiz XVIII. os Bourbons e as monarquias em geral. Se possuia um temperamento muito

49. Vide "Pcquena História da República". 3. ed. Rio de Janeiro: Civilização Brasileira, 1974. p. 31 - grifos nossos

50. Op. cit.p. $31-32$

51. Op. cit. p. 31

52. Op. cit., p. 32 
amigo da ordem (herançu do tradicionalismo de sua familia), era espirito altamente revolucionúrio. Em seus trabalhos sempre defendia a adopção de uma "ditadura republicana" Era tão grande a sua preocupação de ordem, o seu desejo de combater a anarquia de seu tempo, que sua irmã mlle. Alix Comte escreveu-lhe, sugerindo que pusesse o seu talento a serviço do Catolicismo e da realeza tradicional, ao invés de aplicá-lo na elaboração de uma "ordem nova" 53

Quanto aos positivistas ortodoxos brasileiros terem sido republicanos, é preciso enfatizar, com Oliveira Viana, que foram eles positivistas "à sua originalíssima maneira" ${ }^{54}$ Assim, diz sobre eles o autor de "O ocaso do Império":

"Emhora concordando com os outros na superioridade da forma republicana de governo, diferiam deles profundamente em muitos pontos essenciais; im certos pontos estavam em completo antagonismo com os signatários do Manifesto de 1870" 55

Consideramos este "completo antagonismo" de grande significação. Aliás, ressalta Cruz Costa que os rupublicanos eram democratas liberais, ao passo que os positivistas, coerentes com seus princípios, cram a favor de uma república ditatorial.

Em 1881, ocorreu um fato interessante: Tendo o Partido Republicano se habilitado às eleições. obteve o apoio dos positivistas (ortodoxos). Mas, deu-se tal em virtude de uma hábil manobra politica do jornalista Quintino Bocaiuva. Este obtivera a simpatia de Miguel Lemos para a sua candidatura, visto ter declaradu que

53. Vide "O Positivismo No Brasil". Petrupolis: Editora Vozes Lıda., 1943. p. 91 - itálico no original.

54. Vide Oliveira Viana, "O Ocaso do Império" p. 120, apud. Cruz Costa, op. e loc. cit.

55. Vide Oliveira Viana, op. e loc. cit., apud. Cruz Costa, op. e loc. cit. 
era favorável ao advento da república pela evolução. Outra não era a posição do Apostolado. Assim, o apoio foi dado à candidatura Bocaiuva, não ao Partido Republicano. Destarte, efêmera revelou-se tal "aliança" entre os positivistas do Apostolado e os republicanos. Com efeito, a partir dela, e cada vez mais, os positivistas ortodoxos primaram pela observância do elemento religioso existente na doutrina de Comte.

Presos ao elemento religioso, alhearam-se os positivistas ortodoxos da realidade política brasileira, ao passo que seguiam com carinho, tudo o que em França acontecia. Por exemplo, no ano de 1887, os positivistas brasileiros procupavam-se com as dificuldades que o General Boulanger, membro do "povo central" criava à vida republicana francesa. Em todo o caso, pensamos que aqui deve ficar consignado que a preocupação com tudo o que era francês, não se tratava de um apanágio exclusivo dos positivistas: A França era o modelo de tudo o que era bom e belo, na segunda metade do século XIX.

Ora, os positivistas ortodoxos brasileiros, cram coerentes com os ensinamentos do seu mestre Augusto Comte. Assim, respeitavain toda a autoridade constituida. Daí concluir o professor Cruz Costa, que tais homens pouco fizeram para a vinda da República democrática, que consideravam "triste imitação do empirismo francês" 56 Consideramos, inclusive, oportuna a transcrição de uma "nota" à carta que em 1888 os positivistas dirigiram ao bispo do Pará, sobre a liberdade dos cultos. Nela, percebe-se que esses individuos não eram partidários de uma república democrática. A "nota", a despeito de certo hermetismo, é clara. Ei-la:

"Fiéis aos nossos principios, nós, os positivistas. desejariamos que o chefe do Estado compreendesse a situação politica e desse satisfação às justas aspirações populares em vez de esperar que elas venham por órgãos e individuos que, tanto pelo coração como pelo espírito e caráter, se tem patenteado abaixo de tão sublime missão. Se o imperante tomasse a iniciativa que respeitosamente the temos aconsel hado sempre, poderia salvar de nossas instituições politicas atuais o seu elemınto 
verdadeiramente sociocrático, e que consiste na vitaliciedade do supremo funcionário (...) Ao mesmo tempo essa iniciativa dava-lhe o necessário prestígio para estabelecer a sucessão pela forma inaugurada na ditadura romana, designando cada chefe o seu substituto dentro ou fora de sua familia, mediante a aprovação nacional. Por esse modo, em vez de termos uma República, imitação servil de constituições empiricas $e$ viciosas, haveriamos de instituir a forma republicana de acôrdo com as prescrições da moral e da politica cientificas" 57

Em 1888, escrevia Teixeira Mendes, positivista ortodoxo: "O modo pelo qual compreendemos a República nos afasta, não só do neo-republicanismo como mesmo dos que já se denominavam republicanos antes da Lei de 13 de maio" 58 E, efetivamente, assim era: -- pretendiam os positivistas ortodoxos, nada mais, nada menos, que transformar o Imperador em "ditador republicano" E o próprio Teixeira Mendes afirmava que, se viesse a República democrática, "a nossa propaganda continuará a ter por objeto a transformação do presidente metafísico no ditador exigido pela nossa siluação social" 59 Em trabalho que escreveu sobre Benjamin Constant, afirma o mesmo autor: "Nós estávamos alheios a tudo quanto se tramara. Não aconselhamos nem aconselhariamos a revolta, porque seria infringir os preceitos do Mestre" E mais: "Fomos alheios ao levante; não o aconselhamos e nem aconselhariamos, se houvessemos sido previamente consultados" $60 \mathrm{E}$ conclui o Professor Cruz Costa que o Positivismo Orlodoxo em nada contribuiu, em nosso

57. Teixeira Mendes. "in" "A mistificação democrática", p. 13. apud. Cuz Costa, op. cit., p. 33-34 grifos nossos.

58. Vide Cruz Costa. op. cil., p. 34.

59. Vide Teixeira Mendes, "in" "A propósito da agitaçào republicana", p. 28, apud. Cruz Costa, op. e loc. cit. - itálico no original. cit

60. Vide Teixeira Mendes. "in" "Benjamin Constant", v. I, p. 359-361, apud. Cruz Costa, op. eloc. 
meio, para que a República fossc implantada. E tal é confessado pelos próprios chefes do Apostolado Positivista do Brasil, conforme foi visto em Teixeira Mendes."

Se é verdade que o Positivismo ortodoxo em nada contribuiu para que viesse a República, não é possível negar que, por vias indiretas, as idéias de Comte contribuíram para tal advento. Conforme salienta o Professor Cruz Costa, no último quartel do século XIX os clementos mais informados da classe média viviam numa atmosfera positivista, em que se mesclavam, é bom dizer, o fundador da Escola com Littré e Spencer. ${ }^{62}$ Esta assertiva corrobora o que dissemos "retro", a propósito de o Positivismo de Comte e o Evolucionismo de Spencer se misturarem algo indistintamente. no pensamento do século XIX.

A filosofia positiva maior influência teve entre os militares. que entre os civis. É bom lembrar que a República foi feita pela oficialidade jovem, que a dominou de 1889 a 1894. E, na formação da mentalidade dos jovens oficiais, teve papel preponderante Benjamin Constant Botelho de Magalhães, repitamos que professor da Fscola Militar, e um mestre extraordinariamente benquisto entre os cadetes. Benjamin Constant foi personagem de um incidente, que contribuiu para incitar os ânimos, em Outubro de 1889. Em visita à Escola Militar, achava-se a oticialidade do cruzador chileno "Almirante Cochrane"

Estava presente o Ministro interino da Guerra, que não era simpático aos militares. Benjamin Constant compareceu como convidado dos alunos, sendo recebido efusivamente. Nessa ocasião, em discurso, fez referência às questões militares, responsabilizando o governo imperial. E concluiu, fitando o Ministro: "o exército brasileiro não é composto de janizaros; soh a farda de cada soldado pulsa o coração de um cidadão e de um patriota" ${ }^{63}$

Apenas a partir de 26 de outubro de 1889, articularam-se os militares e os civis. para a derrubada da Monarquia. E isto, cremos, demonstra que os positivistas ortodoxos, os civis do "Apostolado" nenhum papel desempenharam na conspiração republicana propriamente dita. Benjamin Constant teve ainda, uma atuação de relevo no sentido de convencer o Marechal Deodoro, que se mostrava indefinido, da necessidade da revolta.

61. Vide Cruz Costa, op. e loc. cit.

62. Vide Cruz Costa, op. cit., p. 34-35.

63. Vide Cruz Costa, op. cit., p. 40. 
Temiam os conspiradures qual seria a atitude de um homem: - Floriano Peixoto, à época, o Ajudante-General do Exército. O Marechal Deodoro tranqüilizou Benjamin Constant e os demais republicanos. Afirmou que. certa vez, pegando num botão da farda, dissera Floriano: - "a monarquia é inimiga disto. Se for para derrubá-la, estarei pronto" 64

Ás seis horas de 15 de novembro de 1889. publicou a "Gazeta da Tarde": - "A partir de hoje, 15 de novembro de 1889, o Brasil entra em nova fase, pois pode-se considerar finda a monarquia. passando a regime francamente democrático com todas as conseqüências da liberdade. Foi o Exército que operou esta magna transformação; assim como em 7 de abril de 1831 ele firmou a monarquia constitucional, acabando com o despotismo do primeiro Imperador, hoje proclama, no meio da maior tranqüilidade e com solenidade verdadeiramente imponente, que queria outra forma de governo. Assim desaparece a única monarquia que existia na América.." 05

A respeito, escreveu o republicano histórico Aristides Lobo: - "O povo assistiu bestializado à Proclamação da República" E opina Cruz Costa que tal atitude era perfeitamente compreensível, "pois a República nada mais foi, uma vez ainda, do que uma nova composição das classes dominantes" ${ }^{66}$ O que o já citado Aristides Lobo chegou a afirmar, também, foi que a instalação do regime republicano foi obra apenas dos inilitares.

João Camilo de Oliveira Torres, em seu "O Positivismo No Brasil", tem um capítulo sob a rubrica "O Positivismo e a República" Nele, demonstra a tese de que o Positivismo. como filosofía política, foi a causa da Repúblic a. Não obstante. o Apostolado Positivista no Brasil pouco fez como causa eficiente para a implantação do novo regime. Para Oliveira Torres, a República foi proclamada porque estavam certos oficiais descontentes com o Império, descontentamento que a História do Brasil conhece como a "Questão Militar" Pois bem, o Positivismo é que teria dado causa à "Questão Militar" E argumenta o autor citado, que se a tal questão fosse simples produto de indisciplina, teria produzido mera mudança de gabinete e não de regime. ${ }^{67}$

64. Vide Cruz Costa, op. cit.. p. 43 - itálico no original.

65. Vide Cruz Costa. op. e loc. cit. - grifos nossos.

66. Vide Cruz Costa. op. cit., p. 45.

67. Vide "O Positivismo no Brasil" cit., p. 95-96. 
Ora, a influência de Benjamin Constant na Escola Militar, produziu o republicanismo no Exército. A influência de Comte, minou a tradição militar brasileira, formando. ironicamente a partir da Escola Militar, a psicologia coletiva de caráter republicano e anti-militarista.

O Comtismo era doutrina nitidamente anti-militar e incompativel com o espirito guerreiro. Nossa Escola Militar, nos fins do Império, estava transformada em "escola de engenharia para soldados" Nela, mesmo os que não eram comtistas eram "positivistas" quer dizer, estavam imbuidos de um estado de espírito cientificista. Operou o positivismo a deformação de nosso militar profissional, transformando-o num bacharel fardado. A propósito. existem vários e interessantes depoimentos. que transcrevemos. Assim para o Capitão Severino Sombra, militar e sociólogo, a influência de Comte foi a "paisanização do Exército brasileiro" Em discurso pronunciado a 15 de novembro de 1938, assim se manifestou o General Leitão de Carvalho: -. "Agravando o perigo, uma exótica influencia filosófica que cortava tradições e arremetia contra o próprio passado de glórias do exército, que fundara o novo regime" 68 Elucidemos que a "exótica influência filosófica" mencionada pelo General Leitão de Carvalho é o Positivismo, que por meio do "Apostolado" atacara as guerras em que o Brasil tomara parte. E assim se manifesta Alberto Rangel, em seu estudo "Gastão d' Orleans - O último conde d' Eu": - "Elementos demagógicos achavam-se, então, espalhados no exército. (...). A vida das guarnições, sobretudo no interior, o exercício das várias comissões, nas fronteiras ou nas capitais das províncias... inutilizavam-Ihes as conspiratas. Havia, entretanto os que atacados do virus paraguaio, admiravam Solano Lopez e reclamavam uma figura semelhante para dominar o Brasil; outros que, imbuidos da glosa pacifista do doutrinarismo comteano, erigido em cartilha de hipóteses falazes e de paródias religiosas, viviam das armas com o desgosto delas, aguardando a Paz Universal de um dia para o outro... Acoimavam-nos de "doutores" os "tarimbeiros", por haverem tarrafeado uma enciclopédia na esfera limitada por idéias sintéticas, fixadas no artifício de um arranjo, puramente mental, e sistemático. Supunham eles, abandonando u metafísica, deter o que haviu de melhor no circulo da inteligência e da cultura humana. Algumas chapas teóricas e dogmáticas, adequavam-se a um feitio de pressuposição, culminada na resistência do entendimento ao que mais preocupa o homem: - a sua essência

68. Op. cit., p. 96 - grifos nossos. 
muterial ou divina, o seu destino morredouro ou imortal... Julgavam, assim, possuir exclusivamente luz das coisas e segredo do saber oniciente, onimodo e onipotente. Tinham resolvido a equação do $2^{\circ}$ grau no cálculo do aterro e do desaterro, e assistido Benjamin Constant, no trampolim das projeções ortogonais, rezar pelo credo de Augusto Comte. Eram gente de outra laia e dai se julgarem só eles capazes de endireitarem a cepa torta do Brasil" ${ }^{69}$ Nota João Camilo de Oliveira Torres que Alberto Rangel tem "expressões por vezes um pouco rudes" aduzindo entrctanto que tal autor estudou na Escola Militar. ${ }^{70}$ Acrescentamos nós que Alberto Rangel sabia do que estava falando. E a presunção intelectual dessa oficialidade jovem, formada por Benjamin Constant, e que, como vimos "retro", dominou a República, de 1889 a 1894, nos traz à mente esta verdade insofismável, que Milovan Djilas demonstrou em seu livro clássico: --- toda revolução leva para o poder uma "nova classe" 71 E a República no Brasil, revolucionária, imposta pelas armas pelos positivistas do Exército, não fugiu a esta regra.

Sobre os efeitos deletérios do Positivismo na formação dos militares da época, é digna de transcrição, a opinião de Oliveira Lima contida "in" "O Império Brasileiro", e reproduzida por João Camilo de Oliveira Torres:

"Formando uma espécic hibrida de hachareis de farda, militares pelo oficio, paisanos pela ambição de classe, que se entregavam muito mais aos debates acadêmicos do que às matemáticas, à estratégia e à balística. Essa oficialidade andava transviada da sua educação profissional pala cultura de uma doutrina filosófica francesa que nem todos digeriam satisfatoriamente, mal grado o bem ordenado de sua sistemarização. O Positivismo era o evangelho da Escola Militar que, oriunda da antiga escola central, depois de ser desdobrada pelo decreto que criou a escola

69. Op. cit., p. 97 - grifos nossos.

70. Op. e loc. cit.

71. Vide "A Nova Classe - Uma análise do sistema comunista", tradução brasileira de Waltensir Dutra. 4. ed. Rio de Janeiro: Livraria Agyr Editôra, 1963. 
Politécnica --- se tornou verdadeiro viveiro de agitadores. Tenentes e capitães mostravam saber de cór A. Comte e Lafitte ''m vez de Jomini e Von der Goltz. Frequentavam seus clubes, discutiam politica e literatura, em vez de currer aos campos de exercicio" 72

Cremos nós que o uso da palavra "Evangelho", por parte do ilustre historiador, é altamente adequado: - Como outras doutrinas que tentaram e tentam tirar, ao homem, a sua dimensão transcendental, v. g. o Marxismo, caiu o Positivismo em uma paródia, por vezes burlesca, das religiões tradicionais... Fduardo Prado, que não era nem positivista. nem republicano, escreveu:

"Já não existe mais o velho militar, descendente direto da milicia portuguesa das campanhas peninsulares... $O$ oficial novo no Brasil ouvia nas escolas o maior número de professores. Esses (pelo menos muito deles) ou são bacharéis discursadores, ou são militares de livro francês, filosofantes do Positivismo, desses que para a exposição desta doutrina tiveram a habilidade de criar no Brasil uma retórica especial... O governo monárquico cometeu um erro imenso, deixando ao ensino militar o seu caráter exclusivamente teórico... O senhor D. Pedro II não jez senão abacharelar o oficial do exército, que agora naturalmente revela pronunciado furor politicamente discursante e manifestante" 73

Aduzimos que estes militares influenciados pelas doutrinas comteanas, a eles transmitidas por Benjamin Constant, eram um material humano de primeira ordem para uma sublevação contra o Imperador, porquanto, esquecida a velha disciplina castrense, herança venurável do Exúrcito Real Português, fícavam

72. Vide "O Positivismo no Brasil" cit. p. 98 - grifos nossos.

73. Transcrito por João Camilo de Olivcira Torres, op. e loc. cit. - grifos nossos. 
esquecidos. por igual, os laços de fidulidade e de lealdade que, tradicionalmente, os ligavam à Casa de Bragança.

Benjamin Constant, já tivemos oportunidade de dize-lo, não era um positivista ortodoxo. Como muito pitorescamente ensina Oliveira Torres, "o celebre lente da Escola Militar, era um herege, como Littré" 74 Pois bem: . Fato significativo, e a nosso ver revelador de "pouca fí religiosa" e, scja-nos permitido dizer isto, de oportunismo. é que, com o advento da República, o Apostolado foi incorporado cumprimentar Bınjamin C'onstant, novo Ministro da Guerra. E a situação anterior, era de rompimento de relações. Conclui Oliveira Torres, com visivel ironia:

"A republica fôra feita por um positivistc . que, apesar de herege, era discipulo de Comte. Logo fíra feita pelo Positivismo" 75

Após a reconciliação do "Apostolado" com Benjamin Constant, o Positivismo literalmente governou o Brasil por dois meses e meio: - de $15 \mathrm{dc}$ novembro de 1889 até a saída de Demétrio Ribeiro (positivista ortodoxo, obediente ao Apostolado e Ministro da Agricultura) do governo, ocorrida em 31 de janeiro de 1890. Salienta Oliveira Torres que, para reagir contra a organização do Brasil segundo a "Politiquc Positive" só existia o bom senso do Marechal Deodoro e o liberalismo juridico de Rui Barbosa e Quintino. ${ }^{76}$ No curto lapso em que estiveram no poder, os positivistas influíram para que fossem adotadas, entre outras, as seguintes medidas: - A bandeira republicana, com o lema "Ordem e Progresso": separação entre Igreja e Estado e o decreto dos feriados.

Como assinala Oliveira Torres, "a República brasileira não era nem queria ser positivista" 77 Sucediam-se os choques entre us positivistas ortodoxos e os demais partidários da República. O fato, a nosso ver, é perfeitamente compreensível, sendo os primeiros, por furmação, homens extremamente dogmáticos,

74. Op. cit., p. 93.

75. Op. e loc. cit. - grifos no original.

76. Op. cil.. p. 102.

77. Op. cit.. p. 109. 
verdadeiramente, "os donos da verdade" A partir de 31 de Janeiro de 1890, data, como vimos, da saída de Demétrio Ribeiro do governo, o "Apostolado Positivista" só influenciou a opinião pública, e não mais teve ingerência direta nos negócios do Estado. ${ }^{78}$

\section{Conclusão}

A conclusão deste pequeno artigo, envolve um aparente paradoxo: - É inegável que foi o Positivismo, graças à influência de Benjamin Constant Botelho de Magalhães, como professor da Escola Militar, a causa da proclamação da República, aos 15 de Novembro de 1889. E isto porquanto, sem a pregação do lente da Escola Militar, não teria existido o braço armado que derrubou o trono imperial. Mas, se foi o Positivismo, lato sensu, esta causa, em nada contribuiu o Apostolado Positivista para a queda da Monarquia. F assim, os verdadeiros adeptos de Augusto Comte, os positivistas ortodoxos, seguidores incondicionais das doutrinas do mestre, não tiveram qualquer participação para que fosse a República proclamada. Lembremos que o Apostolado timbrava por preservar a doutrina de Comte em sua pureza original. Lembremos, mais, que Comte ensinava o respeito à autoridade constituída e a República, entre nós, foi uma sublevação armada. Lembremos ainda que o Apostolado aderiu à República, forjada por Benjamin Constant, que não era positivista ortodoxo, e de quem disse Miguel Lemos, conhecer insuficientemente a doutrina de Comte. Os adeptos ortodoxos de Comte, assistiram surpreendidos à proclamação da República. Havia muito tempo que Miguel Lemos e Teixcira Mendes tinham abandonado a política. E, após a reconciliação do Apostolado com Benjamin Constant, efêmera foi a hegemonia dos verdadeiros positivistas. Para finalizar. cremos ter lançado alguma luz sobre os antecedentes filosóficos e ideológicos dos acontecimentos de Novembro de 1889.

São Paulo, junho de 2004.

78. Op. cil., p. 110. 
6. Bibliografia

CAVAlHEIRO, Edgard. Monteiro Lobato: Vida e Obra. São Paulo: Companhia Distribuidora de Livros / Companhia Editora Nacional, 1955. 2 v.

COSTA, João Cruz. Pequena História da República. 3. ed. Rio de Janeiro: Editora Civilização Brasileira S.A, 1974.

DJlLAS, Milovan. A Nova Classe: uma análisc do Sistema Comunista. Trad. Waltensir Dutra. 4. ed. Rio de Janeiro: Livraria Agyr Editôra, 1963.

MACHADO NETO, A. L. História das idéias juridicas no Brasil. São Paulo: Editorial Grijalbo Ltda / EDUSP, 1969.

NOGUEIRA. José Carlos de Ataliba. António Conselheiro e Canudos. São Paulo: Companhia Editora Nacional, 1972.

Pena sem prisão. 2. ed. São Paulo: Saraiva, 1956.

PAIM, Antonio. História das idéias filosóficas no Brasil. 2. ed. São Paulo: Editorial Grijalbo Ltda / EDUSP, 1974.

PRADO. Eduardo. A ilusão americana. 2. ed. São Paulo: Editora Brasiliense, 1958.

SALGADO, Plínio. História do Brasil. São Paulo: Editora F.T.D., 1970. 2v.

SPENCER, Herbert, Classificação das sciencias. Trad. de M.C. da Rocha. 2. ed. Rio de Janeiro: Laemmert \& C., 1900.

TORRES, João Camilo de Oliveira. O Positivismo no Brasil. Petrópolis: Editora Vozes Ltda.. 1943. 